\title{
Liver abscess secondary to a broken needle migration- A case
} report

\author{
Chintamani*, Vinay Singhal, Parminder Lubhana, Rakesh Durkhere and \\ Shabnam Bhandari*
}

Address: Department of Surgery and Radiology, Vardhman Mahavir Medical College, Safdarjang Hospital, New Delhi-110023, India

Email: Chintamani* - chintamani7@rediffmail.com; Vinay Singhal - chintamani@doctor.com; Parminder Lubhana - chintamani@doctor.com; Rakesh Durkhere - chintamani@doctor.com; Shabnam Bhandari* - chintamani@doctor.com

* Corresponding authors

Published: 07 October 2003

BMC Surgery 2003, 3:8
Received: 10 June 2003

Accepted: 07 October 2003

This article is available from: http://www.biomedcentral.com//47I-2482/3/8

(C) 2003 Chintamani et al; licensee BioMed Central Ltd. This is an Open Access article: verbatim copying and redistribution of this article are permitted in all media for any purpose, provided this notice is preserved along with the article's original URL.

\begin{abstract}
Background: Perforation of gut by sharp metallic objects is rare and rarer still is their migration to sites like liver. The symptoms may be non-specific and the discovery of foreign body may come as a radiological surprise to the unsuspecting clinician since the history of ingestion is difficult to obtain.

Case report: A unique case of a broken sewing needle in the liver causing a hepatic abscess and detected as a radiological surprise is presented. The patient had received off and on treatment for pyrexia for the past one year at a remote primary health center. Exploratory laparotomy along with drainage of abscess and retrieval of foreign body relieved the patient of his symptoms and nearly one-year follow up reveals a satisfactory recovery.

Conclusion: It is very rare for an ingested foreign body to lodge in the liver and present as a liver abscess. An ultrasound and a high clinical suspicion index is the only way to diagnose these unusual presentations of migrating foreign bodies. The management is retrieval of the foreign body either by open surgery or by percutaneous transhepatic approach but since adequate drainage of the abscess and ruling out of a fistulous communication between the gut and the liver is mandatory, open surgery is preferred.
\end{abstract}

\section{Background}

It is not unusual to come across patients with perforation of gastrointestinal tract due to ingested foreign bodies in clinical practice, but the development of a secondary liver abscess is a rare condition. Recently our team successfully managed a patient with liver abscess produced secondary to a broken sewing needle penetration. There is only one previous published article, of Able et al. in 1971 [1]. The first case of hepatic abscess as a result of gastrointestinal perforation caused by a foreign body was published by Lambert in 1898[2]. The usual site of penetration is either stomach or duodenum and it is rare to get a history of ingestion in most of the cases.

\section{Case report}

A 26 year old gentleman presented to the surgical wing with pain right upper abdomen and intermittent high grade fever with chills and rigors along with vomiting off 


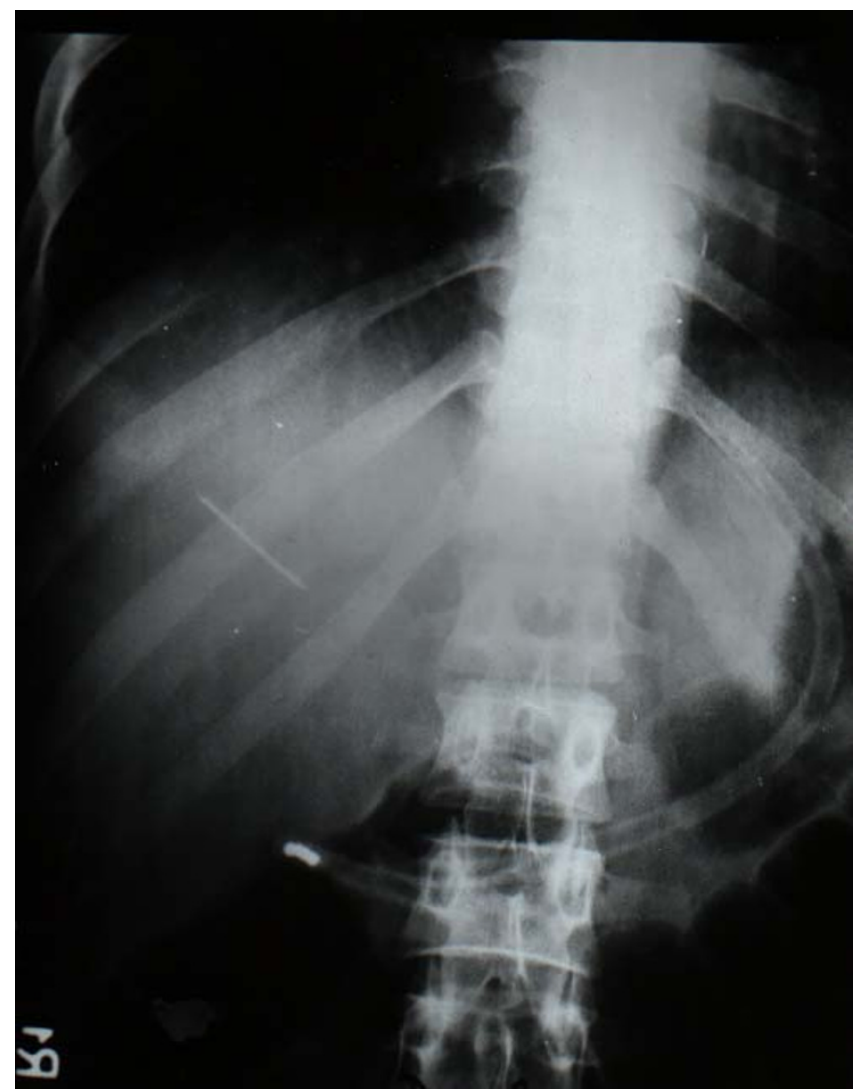

Figure I

Abdominal $x$-ray (AP view) showing the needle in the region of the liver

and on for the last one year. There was no history of jaundice or urinary complaints. He had received treatment for his fever as a case of pyrexia of unknown origin at a remote district hospital in the form of antibiotics, antimalarial drugs and antipyretics with symptomatic relief after each episode. He was referred in view of the recurring and persisting symptoms and lack of facilities for ultrasound and other advanced investigations. Examination revealed a pale, febrile (temp:102*f) and toxic patient with tachycardia (pulse 110/mt), tachypnoea(R/R :20/mt). Abdomen was tense with tenderness in the right hypochondrium without any signs of peritoneal irritation. Liver was enlarged and tender. Blood chemistry was by and large within normal limits except for anaemia(Hb:9 gm\%) and leucocytosis (Total count; 13000/ cumm, polymorphs: $80 \%$ ). Liver function tests were within normal limits except serum alkaline phosphatase which was raised, serum bilirubin and urine examination were normal. X-ray abdomen revealed a foreign body (? needle: fig 1) in the region of the liver. Ultrasound examination of the abdomen (fig 2) and contrast enhanced computed tomography scan(fig 3) confirmed the presence of a needle in the right lobe of the liver along with an abscess of the size $6.5 \times 6 \times 4 \mathrm{~cm}$ in the segment $\mathrm{V}$ (according to the Couinaud's nomenclature of liver segments). Patient was started on $3^{\text {rd }}$ generation cephalosporins(Cefotaxime), Metronidazole and subjected to exploratory laparotomy which revealed multiple adhesions in the region of segment $\mathrm{V}$ of the liver with omentum and duodenum however no obvious fistulous communication between the biliary system and the stomach or duodenum could be appreciated. There was an abscess of the size of $6.5 \times 6 \times 4 \mathrm{~cm}$ in the segment $\mathrm{V}$ (five), about 200 cc of pus was drained and a broken sewing needle of the size $3 \mathrm{~cm}$ (fig 4) was retrieved. After a thorough peritoneal lavage using normal saline and packing the cavity with omentum, abdomen was closed leaving a tube drain in situ. Antibiotics were revised based on the subsequent culture sensitivity report that showed Sretptococcus pyogenes and E. Coli. Postoperative recovery was good and one year follow up reveals a satisfactory outcome. It could be suspected that an accidentally ingested broken sewing needle made its way in to the right lobe of the liver after penetration of the duodenum or stomach as was evident at laparotomy in the form of adhesions between the stomach, duodenum and omentum with the right lobe of liver.

\section{Conclusion and Discussion}

Most ingested foreign bodies pass through the gastrointestinal tract uneventfully within one week[1,3-7]. The reported incidence of foreign bodies penetrating the gut is less than $1 \%$, the objects being pointed or sharp in most of the cases like tooth picks, sewing needles, dental plates, fish bones and chicken bones etc. $[8,9]$. The most common sites of perforation of the gut by foreign bodies are ileocecal junction and recto sigmoid region. The foreign body migrating to liver and producing liver abscess is indeed rare with less than 20 cases reported in the world literature [9]. The classical presentation of hepatic abscess like fever, abdominal pain and jaundice is present in only a small number of patients and may be associated with features of cholangitis like high grade fever with chills and rigors and jaundice. Most patients have non specific symptoms such as anorexia, vomiting or weight loss with leucocytosis or increased transaminases, bilirubin or alkaline phosphatase[10-13] The migrating foreign body may remain silent for a long time and may only be discovered if there are features of infection or abscess formation. In one reported case of unexpected death the cause discovered on autopsy was a migrating foreign body(portion of chicken fibula) and the prolonged time course of illness, with relatively non specific symptoms and signs resulted in establishment of diagnosis only at autopsy[12]. Presentation of a migrating foreign body (tooth pick)as a granulomatous liver abscess has been reported one month after 


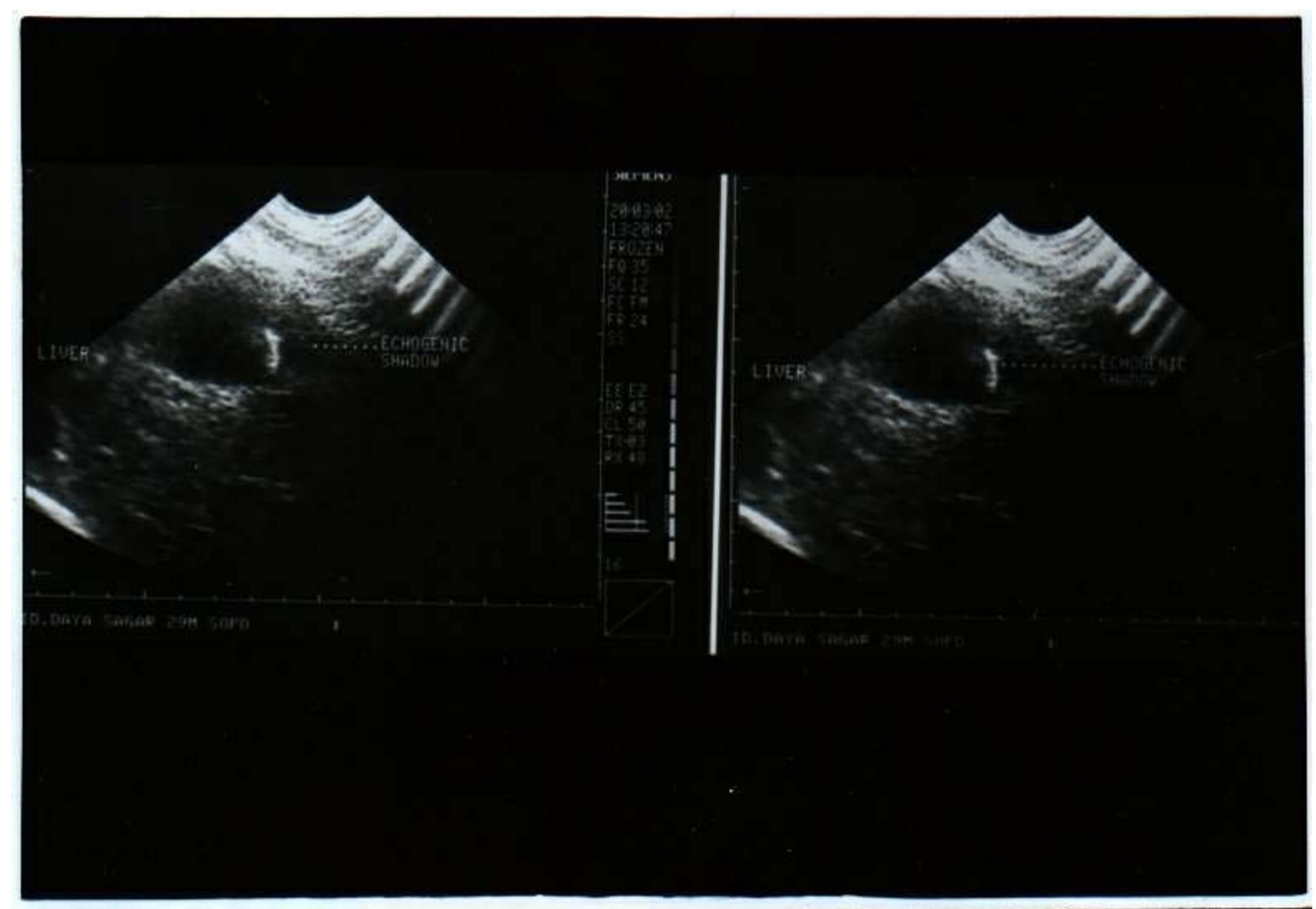

Figure 2

Ultrasound of the abdomen showing the abscess and the needle in the right lobe of the liver

ingestion and it required a partial lateral resection of the granulomatous tumor to retrieve the foreign body and drain the abscess[14]. With no history of foreign body ingestion being usually available these patients have a delayed presentation and may get treated like any other case of pyrexia of unknown origin. The clinical suspicion index has to be high particularly in the absence of specific signs and symptoms. An ingested foreign body may be identified with plain X-ray abdomen, if radio opaque however ultrasound of the abdomen and computed tomography scans are essential in making an accurate localization of the foreign body embedded in the liver [15-20]. Although the site of penetration of the gut may not be ascertained in majority of cases, the usual site of perforation has been observed to be the stomach or duodenum and more commonly the foreign body is lodged in the left lobe of the liver for some unknown reasons (table 1)[9]. Streptococcus constellatus which is found in the mouths of healthy individuals, if grown in the culture of the pus drained from the abscess confirms that the foreign body has been ingested [9]. The recommended treatment is exploratory laparotomy to drain the liver abscess and retrieve the foreign body. There is however one case report of a liver foreign body being retrieved by percutaneous transhepatic approach[9]. The technique involved retrieval through a sinus tract(produced by using a fine fibroscope) using endoscopic forceps under ultrasound guidance. 
Table I:

\begin{tabular}{|c|c|c|c|c|c|c|c|c|c|c|}
\hline Year & Author & Symptom & $\begin{array}{l}\text { Period of } \\
\text { suffering }\end{array}$ & $\begin{array}{l}\text { Foreign } \\
\text { body }\end{array}$ & $\underline{\text { Size }}$ & Penetration & Liver lobe & Bacteria & Laparotomy & Treatment \\
\hline 1971 & Abel et al & None & Unknown & Needle & $2.5 \mathrm{~cm}$ & Stomach & Left & Unknown & Yes & $\begin{array}{l}\text { Removal of needle } \\
\text { and part of liver }\end{array}$ \\
\hline 1971 & Berk et al & $\begin{array}{l}\text { Rt. upper } \\
\text { abdominal pain }\end{array}$ & Weeks & $\begin{array}{l}\text { Chicken } \\
\text { bone }\end{array}$ & $4 \mathrm{~cm}$ & Stomach & Left & Unknown & Yes & $\begin{array}{l}\text { Bone removed, } \\
\text { abscess drained, } \\
\text { hemigastrectomy }\end{array}$ \\
\hline 1981 & Ratizadeh et al & Low grade fever & 10 days & Tooth pick & $4.2 \mathrm{~cm}$ & Duodenum & Left & Streptococcus & Yes & $\begin{array}{l}\text { Removal of foreign } \\
\text { body, abscess } \\
\text { drained }\end{array}$ \\
\hline 1981 & Tsuboi et al & $\begin{array}{l}\text { Epigastralgia, } \\
\text { weight loss }\end{array}$ & I month & Fish bone & $4.7 \mathrm{~cm}$ & Stomach & Left & Unknown & Yes & $\begin{array}{l}\text { Removal of bone, } \\
\text { abscess drained }\end{array}$ \\
\hline 1984 & Bloch et al & $\begin{array}{l}\text { Fever, myalgia, } \\
\text { anorexia }\end{array}$ & 2 weeks & Toothpick & $4.5 \mathrm{~cm}$ & Stomach & Left & Streptococcus & Yes & $\begin{array}{l}\text { Removal and } \\
\text { abscess drainage }\end{array}$ \\
\hline 1986 & Penderson et al & $\begin{array}{l}\text { Abdominal pain, } \\
\text { shock }\end{array}$ & Unknown & Toothpick & $3.5 \mathrm{~cm}$ & Stomach & Left & Unknown & Yes & $\begin{array}{l}\text { Removal and } \\
\text { abscess drainage }\end{array}$ \\
\hline 1988 & Gonzalez et al & $\begin{array}{l}\text { Abdominal pain, } \\
\text { fever, jaundice }\end{array}$ & I month & Fish bone & - & Stomach & Left & Unknown & Yes & $\begin{array}{l}\text { Removal and } \\
\text { abscess drainage }\end{array}$ \\
\hline 1988 & Iwasa et al & $\begin{array}{l}\text { Abdominal pain \& } \\
\text { distension, fever }\end{array}$ & 3 week & Fish bone & $3 \mathrm{~cm}$ & Duodenum & Left & Unknown & Yes & $\begin{array}{l}\text { Lateral } \\
\text { segmentectomy }\end{array}$ \\
\hline 1990 & Dugger et al & $\begin{array}{l}\text { Rt. upper } \\
\text { quadrant pain, } \\
\text { chills, pre-shock }\end{array}$ & 3 week & $\begin{array}{l}\text { Fish or } \\
\text { chicken bone }\end{array}$ & $3.8 \mathrm{~cm}$ & Stomach & Right & $\begin{array}{l}\text { E. coli, } \\
\text { Proteus }\end{array}$ & Death & Autopsy \\
\hline 1991 & Matsunazi et al & $\begin{array}{l}\text { Abdominal pain, } \\
\text { fever, vomiting }\end{array}$ & I week & Fish bone & $4 \mathrm{~cm}$ & Stomach & Left & Unknown & Yes & $\begin{array}{l}\text { Per-cutaneous } \\
\text { drainage, lateral } \\
\text { segmentectomy, } \\
\text { partial gastrectomy }\end{array}$ \\
\hline 1993 & Chen et al & $\begin{array}{l}\text { Epigastralgia, } \\
\text { fever, vomiting }\end{array}$ & 3 months & $\begin{array}{l}\text { Chicken } \\
\text { bone }\end{array}$ & $4 \mathrm{~cm}$ & Duodenum & Left & Unknown & Yes & $\begin{array}{l}\text { Abscess drainage } \\
\text { and closure of } \\
\text { perforation }\end{array}$ \\
\hline 1998 & Horii et al & Spike fever & 2 weeks & Fish bone & $2.8 \mathrm{~cm}$ & Unknown & Left & $\begin{array}{l}\text { Streptococcus } \\
\text { constellatus }\end{array}$ & No & $\begin{array}{l}\text { Per-cutaneous } \\
\text { abscess drainage }\end{array}$ \\
\hline 2003 & Chintamani et al & Fever, vomiting & I year & Needle & $3 \mathrm{~cm}$ & Unknown & Right & Streptococcus & Yes & $\begin{array}{l}\text { Removal of foreign } \\
\text { body and abscess } \\
\text { drainage }\end{array}$ \\
\hline
\end{tabular}

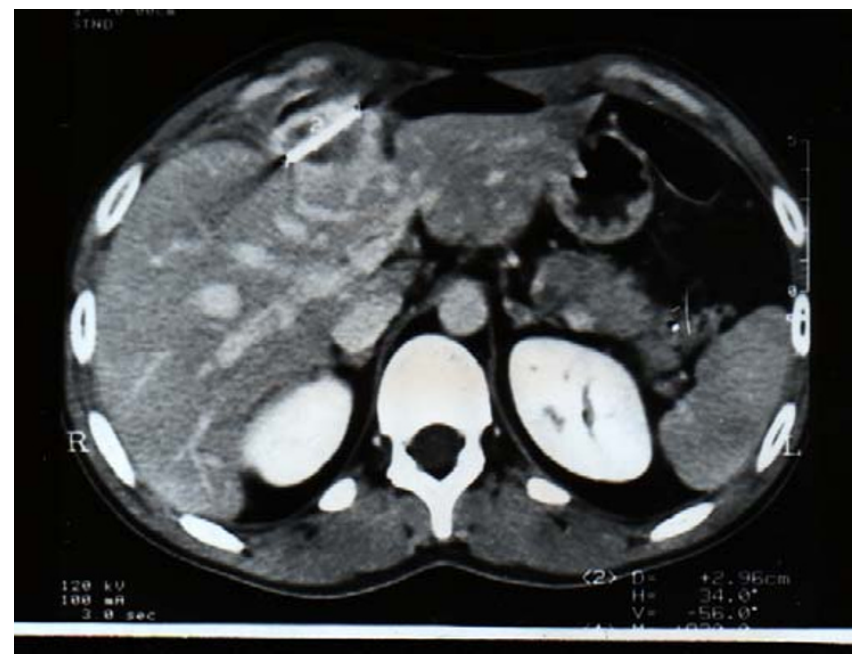

Figure 3

Contrast enhanced computed scan of the abdomen showing the abscess and needle in the right lobe of the liver

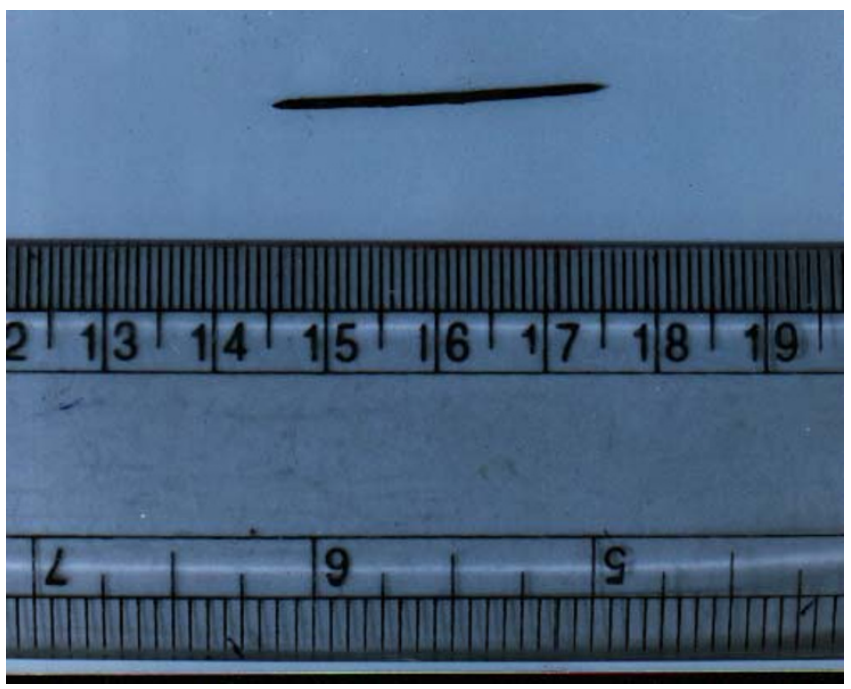

Figure 4

The sewing needle after retrieval 


\section{Acknowledgement}

A written consent was taken from the patient regarding publication of this case report in the Biomed Central Journal

\section{References}

I. Able RM, Fischer JE and Hendren WH: Penetration of the alimentary tract by a foreign body with migration to the liver. Arch Surg 1971, 102:227-28.

2. Lambert A: Abscess of the liver of unusual origin. NY Med J I898: $177-78$

3. Crankson SJ: hepatic foreign body in a child. Pediatr Surg Int 1997, 1 2:426-427.

4. Lofti M: Foreign body in the liver. Int Surg 1976, 6 I:228.

5. Ward A and Ribchester J: Management of ingested foreign bodies in childhood. BM] $1978,4: 469-472$.

6. McCanse DE, Kurchin A and Hmshaw JR: Gastrointestinal foreign bodies. Am J Surg I 98I, I 42:335.

7. Maleki $M$ and Evans WE: Foreign body perforation of the intestinal tract. Report of 12 cases and review of literature. Arch Surg 1970, 102:227-228.

8. Theodoropoulou A, Roussomoustakaki M and Michalodimitrakis $M N$ et al: Fatalliver abscess caused by a fish bone. Lancet 2002, 359(93 I 0): 977 .

9. Kumar S and Gupta NM: Foreign bodies migrating from gut to liver. Indian J Gastroenterol 2000, I 9(I):42.

10. Tsui BC and Mossey J: Occult liver abscess following clinically unsuspected ingestion of foreign bodies. Can J Gastroenterol 1997, I I (5):445-8.

II. Horii K, Yamazaki $O$ and Matsuyama $M$ et al.: Successful Treatment of a Hepatic Abscess that Formed Secondary to Fish Bone Penetration by Percutaneous Transhepatic Removal Of Foreign Body: Report of a Case. Jpn J Surg 1999, 29:922-926.

12. de la Vega M, Rivero JC, Ruiz $L$ and Suarez $S: A$ fish bone in the liver. Lancet 200I, 358:982.

13. Chen SM, Shen MT and Lo GH: Duodenal perforation with liver abscess caused by ingestion of a chicken bone. Chin J Gastroenterol 1993, 10:312-319.

14. Bloom RR, Nakano PH and Grey SW et al:: Foreign bodies of the gastrointestinal tract. Am Surg 1986, 52:618-21.

15. Byard RW and Gilbert JD: Hepatic abscess formation and unexpected death:a delayed complication of occult intraabdominal foreign body. Am J Forensic Med Pathol 200I, 22(I):88-9I.

16. Kanazawa $\mathrm{S}$, Ishigaki $\mathrm{K}$ and Miyake $\mathrm{T}$ et al:: a granulomatous liver abscess which developed after a tooth pick penetrated the intestinal tract: report of a case. Surg Today 2003, 33(4):3 I2-4.

17. Drnosvsek V, Fontanez-Garcia D, Wakabayashi MN and Plavsic BM: Gastrointestinal case of the day. Pyogenic liver abscess caused by perforation caused by a swallowed wooden toothpick. Radiographics 1999, I9(3):820-2.

18. Broome CJ and Peck RJ: Hepatic abscess complicating foreign body perforation of the gastric antrum: an ultrasound diagnosis. Clin Radiol 2000, 55:242-43.

19. Masunaga S, Abe M and Imura T: Hepatic abscess secondary to a fish bone penetrating the gastric wall: CT demonstration. Comp Med Imag Graph 1991, I 5:1 I3-116.

20. Strauss JE, Balthazar FJ and Naidieh DP: Jejunal perforation by a tooth pick: CT demonstration. J Comput Assist Tomogr 1985, 9:8|2-8|4.

\section{Pre-publication history}

The pre-publication history for this paper can be accessed here:

http://www.biomedcentral.com/1471-2482/3/8/prepub
Publish with Biomed Central and every scientist can read your work free of charge

"BioMed Central will be the most significant development for disseminating the results of biomedical research in our lifetime. "

Sir Paul Nurse, Cancer Research UK

Your research papers will be:

- available free of charge to the entire biomedical community

- peer reviewed and published immediately upon acceptance

- cited in PubMed and archived on PubMed Central

- yours - you keep the copyright

Submit your manuscript here:

http://www.biomedcentral.com/info/publishing_adv.asp
BiolMedcentral 